\title{
Dietary polyunsaturated fatty acids and their metabolites: Implications for diabetes pathophysiology, prevention, and treatment
}

\author{
Joshua C. Neuman ${ }^{\mathrm{a}, \mathrm{c}}$, Rachel J. Fenske ${ }^{\mathrm{a}, \mathrm{c}}$ and Michelle E. Kimple $\mathrm{K}^{\mathrm{a}, \mathrm{b}, \mathrm{c}, *}$ \\ ${ }^{a}$ Interdisciplinary Graduate Program in Nutritional Sciences, University of Wisconsin-Madison, Madison, \\ WI, USA \\ ${ }^{\mathrm{b}}$ Department of Medicine, Division of Endocrinology, University of Wisconsin-Madison School of Medicine \\ and Public Health, Madison, WI, USA \\ ${ }^{\mathrm{c}}$ Research Service, William S. Middleton Memorial Veterans Hospital, Madison, WI, USA
}

\section{Introduction}

In 2013, the global burden of diabetes was estimated to be 382 million individuals, increasing to almost 592 million by 2035 [1]. The economic burden of diabetes is also high, in part due to chronic comorbidities such as cardiovascular and renal disease. US healthcare spending because of diabetes and its complications reached almost $\$ 306$ billion in 2012 [2]. Of note, the aging population, specifically those over 65 , are expected to experience the greatest increase in diabetes incidence, with a $134 \%$ increase by year 2030 [3]. Although the increased diabetes prevalence in the aged population may be explained partly by reduced all-cause mortality due to the advances of modern medicine, sedentary lifestyle and poor dietary habits are major risk factors for diabetes and are highly associated with the onset and rapid progression of diabetes.

\footnotetext{
*Corresponding author: Michelle E. Kimple, PhD, Assistant Professor of Medicine, Division of Endocrinology, Diabetes and Metabolism, University of Wisconsin-Madison, $4148 \mathrm{UW}$ Medical Foundation Centennial Building, 1685 Highland Ave., Madison, WI 53705, USA. Tel.: +1 608616 0138; E-mail: mkimple@medicine.wisc.edu.
}

The modern food supply has evolved from that of our distant ancestors because of advances in agriculture, technology, and economic interest. Not only has an increased food supply made it easier for individuals in industrialized countries to consume a greater number of calories, but also the nutritional composition of that food supply continues to change. One class of nutrients that is drastically diverging from that of our ancestors is dietary fat, a fact that may play a key role in the rising prevalence and progression of certain diseases, particularly those of aging (Fig. 2) [4]. For instance, the ratio of diet-derived omega6 to omega-3 polyunsaturated fatty acids (PUFAs) has been linked to the progression of a number of chronic diseases, including diabetes [5]. Long-chain PUFAs (LCPUFAs), such as arachidonic acid (AA) and eicosapentaenoic acid (EPA), have long been known to contribute to the structural integrity of cell membranes and provide a fuel source for the cell, but more recently their functional capacity as signal transduction mediators has come to light. Intact LCPUFAs can act as potent ligands for cellular and nuclear receptors, or can be modified into bioactive compounds to further cellular signaling cascades [6-8]. As we and others are actively studying signaling mediated by LCPUFAs and their metabolites, 
a research area ripe with conflicting results and recommendations, we sought to complete a comprehensive review of the published literature regarding what is currently known about the pro- and antidiabetic actions of LCPUFAs and their metabolites in cells, model organisms, and humans. Ultimately, we also provide conclusions and future perspectives based on this comprehensive literature review, which describes the cellular signaling roles of LCPUFAs and their respective metabolites in the development, progression, and treatment of diabetes.

\section{Free fatty acids as signaling molecules}

It is well documented that fatty acids contribute to blood glucose regulation and the pathogenesis of diabetes. Acute changes in circulating free fatty acids (FFAs), such as during the transition from a fasted to fed state, stimulate insulin secretion by directly acting on the $\beta$-cells of the pancreatic islet. FFAs can also maintain a basal level of insulin secretion during a prolonged fast to limit tissue lipolysis and, ultimately, ketoacidosis [9]. However, chronic exposure to FFAs blunts insulin secretion by potentially creating a lipotoxic environment, leading to increased $\beta$-cell cytotoxicity and apoptosis [10]. Chronically elevated FFAs also contribute to insulin resistance, as GLUT4 transport in muscle is blunted, interfering with peripheral glucose sensing $[11,12]$.

Although chronic exposure to FFAs collectively contributes to blood glucose deregulation, certain FFA species, including LCPUFAs, can explicitly affect insulin secretion and sensitivity by binding to extracellular membrane receptors (Fig. 1). Gprotein-coupled receptors (GPCRs) are ubiquitously expressed seven transmembrane receptors that, when bound by a ligand, change conformation to transmit an intracellular signal via guanine nucleotide-binding proteins (G-proteins) [13]. Collectively, there are four major groups of $G$-proteins $-G_{s}, G_{i}, G_{q}$, and $\mathrm{G}_{12}$-each of which modulate different secondary messenger molecules and elicit different cellular responses [14]. $G_{s}$ and $G_{i}$ increase or reduce cAMP production by activating or deactivating adenylate cyclase activity, respectively. Moreover, $\mathrm{G}_{\mathrm{q}}$ increases liberation of inositol triphosphate and diacylglycerol from the plasma membrane by activating phospholipase $\mathrm{C}$ while $\mathrm{G}_{12}$ activates the small G-protein Rho, which has been shown to play a role in cellular remodeling $[14,15]$.

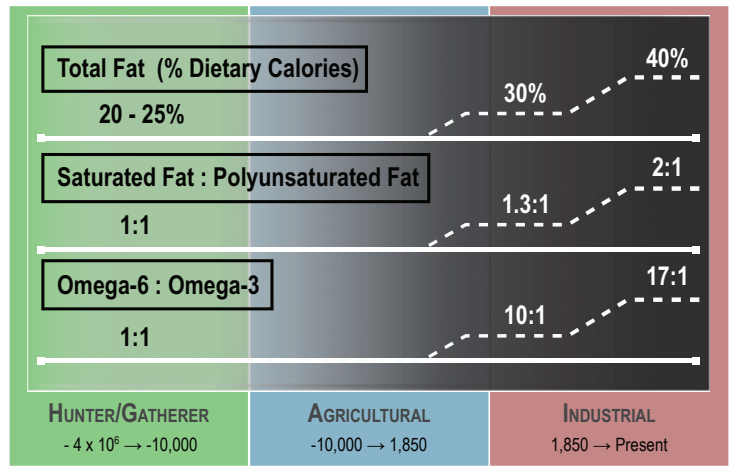

Fig. 1. Dietary fat composition changes over human existence. Human food composition has changed considerably over the course of time. Dietary fat accounted for at most $25 \%$ of total calories in the early Hunter/Gatherer time period but has increased to as much as $40 \%$ in the present day. The fat composition in the diet has also changed over time, with a higher ratio of saturated fat to polyunsaturated fat and a greater omega- 6 to omega- 3 ratio in the modern era when compared to earlier time periods. (Figure adapted from [4]).

Extensive work in isolated islets and $\beta$-cell models demonstrates the importance of the activation or repression of signaling through various GPCRs based on the G-proteins they couple to. For instance, the incretin glucagon-like peptide-1 (GLP-1) is released from L-cells of the intestine and enhances insulin secretion and $\beta$-cell replication and proliferation via the $\mathrm{G}_{\mathrm{s}}$-coupled GLP-1 receptor protein [16-19]. Also, extracellular nucleotides appear to play an important role in enhancing insulin secretion through the $\mathrm{G}_{\mathrm{q}}$-coupled P2Y6 receptor in islets [20]. Moreover, E-series prostaglandins reduce insulin secretion through the $\mathrm{G}_{\mathrm{i}}$-coupled E-prostanoid receptor 3 (EP3) in islets and multiple $\beta$-cell lines, which is upregulated in type-2 diabetes [21-23]. Much less known about the $G_{12}$ group and $\beta$-cell function, but activation of receptors coupled to $\mathrm{G}_{12}$ proteins are linked to exocytosis and secretion [15, 24]. Thus, G-proteins serve important roles in mediating extracellular signals from GPCRs to modulate $\beta$-cell physiology.

A number of GPCRs specific for FFAs or their derivatives have been identified. Furthermore, a number of these receptors have been characterized as regulating glucose homeostasis. GPR41 and GPR43 bind short-chain fatty acids such as and have been implicated in insulin and leptin secretion and signaling [25]. GPR119 is a receptor for derivatives of phospholipids and sphingolipids, and has been shown to directly promote insulin and GLP-1 secretion 


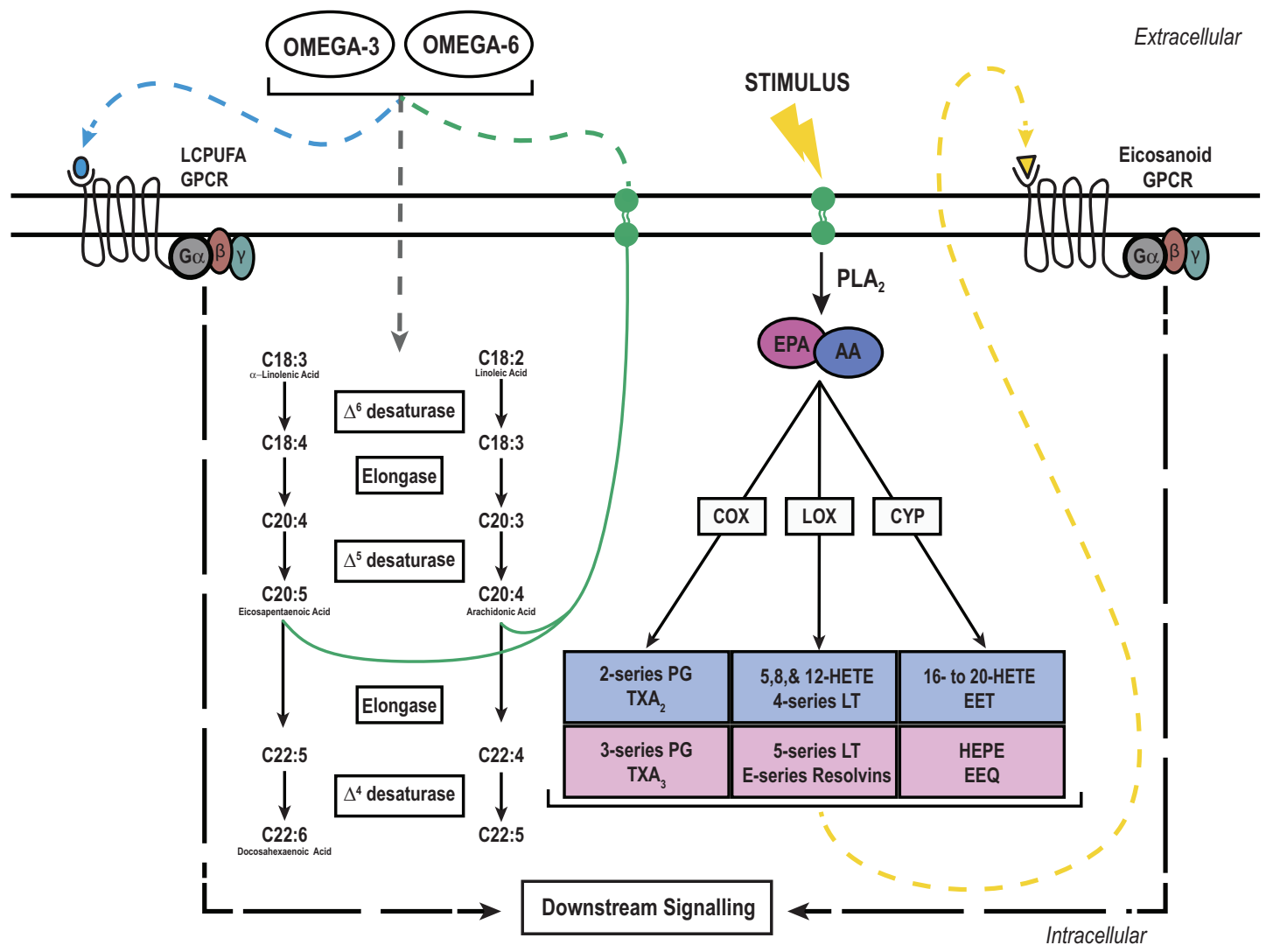

Fig. 2. Long chain polyunsaturated fatty (LCPUFA) signaling and metabolism: LCPUFAs, namely omega- 6 and omega-3, must be derived from the diet to elicit intracellular signaling cascades through G-protein coupled receptors (GPCRs) or be incorporated into the cellular membrane for future use. Shorter omega- 6 or -3 LCPUFAs like linoleic or $\alpha$-linoleic acid, respectively, can be further metabolized by the same enzymes to yield the longer LCPUFAs arachidonic acid (AA) or eicosapentaenoic acid (EPA). Newly formed AA and EPA can then be incorporated into the phospholipid membrane for future use. Upon an external stimulus like a cytokine or growth factor, AA and EPA can be liberated from the membrane by phospholipase $\mathrm{A}_{2}\left(\mathrm{PLA}_{2}\right)$ and metabolized into bioactive compounds by the rate limiting enzymes cyclooxygenase (COX), lipoxygenase (LOX), or cytochrome P450 (CYP). These bioactive compounds can then activate extracellular GPCRs in an autocrine or paracrine fashion to elicit downstream signaling cascades.

[26-29]. Extensive reviews of these and other GPCRs, G-proteins and their downstream targets are beyond the scope of this review but can be found elsewhere [30, 31].

Like the FFA species described above, LCPUFAs are endogenous ligands for a subset of GPCRs that are found in unique expression patterns across tissues and play important roles in regulating glucose metabolism. GPR40 is a known lipid-binding GPCR and is highly expressed in the pancreas, with highest concentrations in the insulin-secreting $\beta$ cells [32-34]. When GPR40 is bound to one of a number of LCPUFAs, such as linoleic acid or AA, insulin secretion is potentiated from the MIN6 mouse insulinoma $\beta$-cell line [33]. Additionally, GPR40 knockout mice experience fasting hyperglycemia, insulin resistance, and obesity as compared to their wild-type littermate controls, indicating an important role for GPR40 in whole body glucose metabolism [35]. The notion that activators of GPR40 are essential fatty acids and must be derived from the diet makes it a potential target for a dietary therapeutic intervention as a treatment for diabetes. A recent human study revealed short-term improvements in insulin secretion with GPR40 agonist treatment, although other results were mixed [36-39]. Furthermore, thiazolidinediones, an established class of insulin-sensitizing diabetes therapeutics known primarily as peroxisome proliferator-activated receptor ligands, also appear to activate GPR40, providing an additional explanation to the drugs' action and efficacy [34]. 
GPR120 is another receptor for LCPUFAs linked to the development of obesity and diabetes in both mice and humans [40, 41]. Of the LCPUFA family, GPR 120 has the highest affinity for omega-3 PUFAs [41, 42]. GPR120 expression is limited to lung, adipose tissue, macrophages, and enteroendocrine cells, and its signaling capability at these tissues is quite high [41, 43-45]. With high expression levels in enteroendocrine cells, LCPUFA signaling through GPR120 increases secretion of a number of incretin hormones, including cholecystokinin (CCK), gastric inhibitory peptide (GIP), and GLP-1 [43-45]. Moreover, GPR120 expression in macrophages helps promote a key anti-inflammatory signaling cascade that enhances insulin-sensitizing effects, preventing glucose intolerance [41].

Collectively, GPCRs activated by FFAs or their derivatives, including LCPUFAs, serve as excellent targets to help regulate blood glucose. Whether signaling through these GPCRs directly affects $\beta$-cells, enhances insulin sensitivity, or regulates weight gain, targeting these receptors may be beneficial as diabetes therapeutics.

\section{Eicosanoids as mediators of blood glucose}

In conjunction with LCPUFAs acting as signaling molecules in their unaltered form, the essential omega-3 and -6 LCPUFAs can be metabolized into bioactive compounds termed eicosanoids (Fig. 1). Although eicosanoids derived from the omega- 6 LCPUFA arachidonic acid (AA) are traditional focal points in the literature, having been linked with inflammation and exacerbation of many chronic diseases, emerging evidence regarding EPA (i.e., omega-3)-derived eicosanoids has shown these may have a protective effect, even competing with omega6-derived eicosanoids.

AA and EPA may be consumed in the diet and can be metabolized to form bioactive eicosanoids. However, the 18-carbon omega-3 and -6 LCPUFAs, $\alpha$-linolenic and linoleic acid, respectively, represent a larger portion of the diet and can be elongated and desaturated in mammalian systems to produce the required substrates for eicosanoid production. Interestingly, omega-3 and -6 LCPUFAs compete for the same elongase and desaturase enzymes, linking dietary LCPUFA composition to substrate availability and eicosanoid production [46, 47]. But, this process is severely limited in mammalian systems and only accounts for a small amount of AA and EPA.
$\gamma$-Linoleic acid (GLA), AA, and EPA are 20-carbon LCPUFAs that can be metabolized into bioactive eicosanoids such as prostaglandins, leukotrienes, and hydroxyeicosatetraenoic acids [47]. Eicosanoid production initiates with an external stimulus, such as a cytokine or hormone, and leads to the hydrolysis of GLA, AA, or EPA from the phospholipid membrane by phospholipase $A_{2}$ [7]. After liberation from the membrane, LCPUFAs may still act as signaling molecules and effect cellular function or be metabolized by cyclooxygenase (COX), lipoxygenase (LOX), or cytochrome P450 (CYP450) into substrates for a number of eicosanoid specific enzymes $[7,48]$. However, this process is tightly controlled to prevent aberrant eicosanoid production.

The initiation of eicosanoid production comes from an extracellular stimulus, such as a cytokine, which promotes the activation of multiple downstream enzymes [49]. Phospholipase $\mathrm{A}_{2}\left(\mathrm{PLA}_{2}\right)$ is the class of enzymes responsible for liberating LCPUFAs from the phospholipid membrane to initiate eicosanoid biosynthesis, and activation of $\mathrm{PLA}_{2}$ is modulated by phosphorylation [50, 51]. Moreover, eicosanoid production is limited to discrete locations in the cell, as most eicosanoid production occurs in close proximity to the PLA 2 enzymes at specific organelles [49]. In conjunction with the distinct location of substrate and enzymes within the cell, eicosanoids have a relatively short half-life, which limits continuous agonism of receptors and propagation of intracellular signals [52]. Therefore, strict regulation of eicosanoid production prevents perturbed signaling.

Eicosanoids can be transported from the cell and agonize receptors in a paracrine or autocrine manner to alter cellular function. A number of these compounds are linked to diabetes and have profound effects on insulin sensitivity and secretion in obesity-linked type 2 diabetes and $\beta$-cell health in autoimmune-linked type 1 diabetes. First, we will discuss the much more widely-studied AA-derived eicosanoids, finishing with what is currently known about the effect of EPA-derived eicosanoids on factors contributing to diabetes pathophysiology.

\section{Cyclooxygenase (COX) metabolites}

Prostaglandins are eicosanoids derived from the cyclooxygenase (COX) biosynthetic pathway. COX enzymes exist in two isoforms: the constitutive form, COX-1 and the inducible form COX-2. In most 
cell types the induction of COX-2 occurs following activation by certain pro-inflammatory cytokines and growth factors [53]. Interestingly, COX-2 is the dominant and constitutively expressed isoform expressed in $\beta$-cells, having a profound influence on prostaglandin formation and insulin secretion [54, 55]. Collectively, there are 5 major AA-derived, or 2-series, prostaglandins that bind to distinct GPCRs that are linked to inflammation and disease [56]. It is well documented that prostaglandin production and signaling occurs in both healthy and diabetic islets and can lead to a profound influence on function, proliferation, and survival [21,57-60]. Prostaglandin production and signaling influences both insulin secretion and sensitivity, making them a popular target for therapeutic intervention in diabetes.

It was initially demonstrated that one particular class of bioactive LCPUFA metabolites, called Eseries prostaglandins, reduce insulin secretion both in vitro and in vivo [61, 62]. Moreover, it is well characterized that the AA-derived prostaglandin E2 $\left(\mathrm{PGE}_{2}\right)$ is the predominant E-series prostaglandin formed by COX-2 in islets $[7,54]$. $\mathrm{PGE}_{2}$ binds to a class of ubiquitously expressed GPCR E-prostanoid receptors (EP) that vary in their signaling cascades [56]. Previous work indicates that the $\mathrm{EP}_{3}$ isoform, which couples to an inhibitory G-protein, is the most highly expressed E-prostanoid receptor in islets and we, along with others, have shown that agonism of $\mathrm{EP}_{3}$ in $\beta$-cells with $\mathrm{PGE}_{2}$ leads to a reduction in insulin secretion [21, 63]. Moreover, we confirmed that $\mathrm{PGE}_{2}$ production and $\mathrm{EP}_{3}$ expression are both increased in type 2 diabetic human and mouse islets, and that this production was a significant contributor to diabetic $\beta$-cell dysfunction [21].

In addition to directly limiting insulin secretion, $\mathrm{PGE}_{2}$ may also have a profound influence on insulin sensitivity, although its exact effect remains controversial. It has been shown that $\mathrm{PGE}_{2}$ disrupts insulin signaling and glycogen synthesis via the $\mathrm{EP}_{3}$ receptor in cultured hepatocytes [64]. Moreover, $\mathrm{PGE}_{2}$ production in liver Kupffer cells disrupts hepatocyte insulin signaling and promotes insulin resistance. It is postulated that altered cytokine production in non-parenchymal cells may contribute to insulin resistance [65]. In another study, rats fed a high fat diet with selective COX-2 inhibitors were less insulin resistant and had reduced hepatic glucose production compared to their control counterparts [66]. Similar results were demonstrated in high fructose- and high fat-fed rats given a selective COX-2 inhibitor $[67,68]$. In contrast, others have demonstrated $\mathrm{PGE}_{2}$ may have protective effects on insulin sensitivity. In one study, FFA-induced COX-2 activity and $\mathrm{PGE}_{2}$ production in muscle cells led to improved insulin sensitivity, whereas treatment with a COX-2 inhibitor reversed this protection [69]. Another group demonstrated that increased hepatic COX-2 expression and $\mathrm{PGE}_{2}$ production protected against insulin resistance in diet-induced obese in mice [70]. Therefore, the influence of $\mathrm{PGE}_{2}$ on insulin resistance is controversial and warrants future investigation.

Since $\mathrm{PGE}_{2}$ is the most abundant endogenous AA-derived prostaglandin, the others have received considerably less attention in the literature. However, emerging evidence indicates other AA-derived prostaglandins may prove beneficial for insulin secretion and sensitivity. These additional AA-derived prostaglandins include $\mathrm{PGD}_{2}, \mathrm{PGF}_{2} \alpha, \mathrm{PGI}_{2}$, and thromboxane $\mathrm{A}_{2}\left(\mathrm{TXA}_{2}\right)$.

Like $\mathrm{PGE}_{2}, \mathrm{PGD}_{2}$ appears to be fairly abundant in isolated rat islets and is produced in human islets incubated with AA [71, 72]. Evidence for a direct effect of $\mathrm{PGD}_{2}$ on insulin secretion from $\beta$-cells is weak, although there is stronger evidence of a role for $\mathrm{PGD}_{2}$ in regulating islet $\alpha$-cell glucagon secretion, the counter-regulatory hormone to insulin [73]. Moreover, a mouse model that over-produces $\mathrm{PGD}_{2}$ gained more weight on a high-fat diet when compared to their wild-type counterparts but had enhanced insulin sensitivity [74]. When a form of $\mathrm{PGD}_{2}$ synthase is knocked out in mice fed a high-fat diet they become insulin insensitive, further indicating the importance of $\mathrm{PGD}_{2}$ in insulin signaling [75].

$\mathrm{PGF}_{2} \alpha$ is also expressed in rodent and human pancreatic islets $[71,72] . \mathrm{PGF}_{2} \alpha$ appears to directly stimulate insulin and glucagon secretion in rat pancreases perfused with $\mathrm{PGF}_{2} \alpha$ [76]. However, an isomer of $\mathrm{PGF}_{2} \alpha, 8$-epi- $\mathrm{PGF}_{2} \alpha$, is elevated in plasma from type 2 diabetics and may contribute to the progression of the disease [77, 78].

Classic studies demonstrating the influence of $\mathrm{PGI}_{2}$ on insulin secretion are fairly ambiguous. $\mathrm{PGI}_{2}$ infusion increases blood glucose in rabbit and human test subjects, but this was not linked to changes in insulin secretion [79, 80]. Moreover, the influence of $\mathrm{PGI}_{2}$ on insulin secretion was dependent not only on its own concentration, but also that of glucose, in an isolated rat islet model $[81,82]$. More recently, when production of $\mathrm{PGI}_{2}$ was upregulated in an insulinoma cell line, there was a concomitant increase in insulin secretion in the presence of stimulatory glucose [83]. 
Finally, thromboxane $\mathrm{A}_{2}\left(\mathrm{TXA}_{2}\right)$, does not appear to have an influence on insulin secretion as demonstrated in perfused rat pancreases [73]. However, $\mathrm{TXA}_{2}$ may have a more important role in the cardiovascular disease risk, as type 2 diabetic platelets have enhanced $\mathrm{TXA}_{2}$ production leading to increased activation and aggregation [84-86].

\section{Lipooxygenase (LOX) metabolites}

Lipooxygenase (LOX) enzymes, which include 5LOX, 8-LOX, 12-LOX, and 15-LOX, utilize AA to synthesize hydroxyeicosatetraenoic acids (HETEs) and leukotrienes (LTs) and are categorized based on where they oxygenate AA [7, 87]. Similarly to prostaglandins, HETEs and LTs bind to GPCRs, and can play a role in regulating blood glucose by influencing insulin secretion and sensitivity.

In rat islets, 12-HETE is the most abundant product of the LOX pathway and is produced in fairly large quantities during glucose-induced insulin secretion, whereas 5-HETE and 15-HETE could not be detected or were only minor species [88-91]. Moreover, the addition of exogenous 5-, 12-, or 15-HETE did not result in enhanced insulin secretion, indicating that the production of HETEs alone may not directly impact insulin secretion [91]. This is in contrast to another study, where rat islets treated with exogenous 11-HETE or 15-HETE both had reduced insulin secretion [92]. Interestingly, mice lacking 5LOX have $\beta$-cell hyperplasia and hypertrophy but have blunted insulin secretion and are not insulin resistant. Moreover, insulin secretion is reduced when 5-LOX is knocked down by siRNA in human islets. These results suggest an important role for 5-HETE production and signaling for islet function in both humans and mice [93].

Interestingly, an unstable intermediate of HETE metabolism, 12 hydroperoxyeicosatetraenoic (12HPETE), potentiated insulin secretion in the presence of glucose, suggesting that labile products from this pathway may play a greater role in $\beta$-cell function $[58,92]$. Conversely, it was shown in human islets that exogenous treatment with the 12(S)HETE stereoisomer reduces insulin secretion and increases cell death [94]. Similarly, 12-HETE production is closely linked to $\beta$-cell destruction by immune cells in mouse islets and mice lacking the 12LOX enzyme are protected from chemically-induced type 1 diabetes [95, 96]. Thus, the production of 12-HETE may be important for immune modula- tion as opposed to function during $\beta$-cell glucose metabolism.

In adipocytes, both 12- and 15-HETE may contribute to insulin resistance. Mice fed a high fat diet have an upregulation of 12-LOX and 15-LOX in adipose tissue, and insulin signaling was impaired when adipocytes were treated with either 12- or 15-HETE [97]. Remarkably, 12-LOX knockout mice are protected from developing insulin resistance and $\beta$-cell destruction when fed a high-fat diet [98]. 12-LOX gene expression and 12-HETE production is upregulated in adipose tissue and islets from the Zucker diabetic rat, linking this pathway to the progression and development of insulin resistance in type 2 diabetes $[99,100]$. Moreover, it was shown that rat islets treated with exogenous 11-HETE, 15-HETE, $\mathrm{LTB}_{4}$, and $\mathrm{LTC}_{4}$ all inhibited insulin secretion [92]. Although they may not appear to be endogenous islet products, islet immune cell infiltration and subsequently eicosanoid production during diabetes may contribute to defects in insulin secretion or $\beta$-cell destruction, as demonstrated in a mouse model of type-1 diabetes [101].

\section{Cytochrome P450 (CYP) metabolites}

Similarly to LOX enzymes, CYP enzymes can also synthesize HETEs from AA, but also generate epoxyeicosatrienoic acids (EETs), with number designations for the site of epoxidation [7, 102]. However, much less is known regarding the influence of CYP450 metabolites and their impact on insulin secretion.

One of the initial studies assessing the influence of CYP450 metabolites on $\beta$-cell function only found 5,6-EET to potentiate insulin secretion whereas 8,9-, $11,12-$, and 14,15-EET had no effect on insulin secretion but did increase glucagon production in rat islets [103]. Moreover, it was shown that a prominent CYP enzyme, CYP2J2 in humans and CYP2J3 in rats, is highly expressed in islets in addition to endogenous production of EETs as determined by gas chromatography/mass spectrometry indicating a potential role for EET biosynthesis in islets [104]. Unfortunately, EETs are short-lived in vivo making it difficult to accurately quantify them. Recent work, however, determined that selectively inhibiting or knocking out a soluble epoxide hydrolase (sEH), an enzyme responsible for the metabolism of EETs, protected mice from chemically induced glucose intolerance and enhanced insulin secretion [105]. This phenotype 
was further recapitulated in a diet-induced obese mouse model treated with selective sEH inhibitors or with sEH-null mice, which led to improved insulin sensitivity and greater islet size [106]. Furthermore, a genetic mutation in the human SEH gene EPHX2 that reduces the efficacy of the enzyme improves insulin sensitivity and increases EET production [107]. Thus, it appears that EET degradation may be a critical component in glucose regulation and may serve as a potential target for the treatment of diabetes.

\section{Omega-3 fatty acids: From mouse models to eicosanoids}

Similarly to the competition between omega- 3 and -6 fatty acids for the elongase and desaturase enzymes, EPA and AA utilize and compete for the same enzymes required for eicosanoid biosynthesis [46]. Generally, omega-3 derived eicosanoids are considered less inflammatory compared to omega- 6 derived eicosanoids and are shown to be protective in many cardiovascular based diseases including atherosclerosis, hypertension, and thrombosis [108]. In contrast to the strong evidence supporting the benefits of omega-3 LCPUFAs on cardiovascular function, the current evidence regarding the beneficial effect of increased omega-3 fatty acid consumption as a method to enhance insulin secretion and sensitivity is controversial [109-114]. Unfortunately, high omega3 fatty acid feeding studies in rodents tend to hinder weight gain, making it difficult to attribute metabolic findings to omega-3 fatty acids or lack of weight gain [115]. Furthermore, the direct role of EPA-derived eicosanoids on insulin secretion and insulin sensitivity is poorly characterized. However, emerging work utilizing transgenic mouse models engineered to shift the endogenous ratios of omega- 3 and -6 fatty acids may provide a better understanding of how omega- 3 metabolites and eicosanoids contribute to protection from and progression of diabetes.

A mouse model engineered to express the fat-1 gene from Caenorhabditis elegans is capable of desaturating omega- 6 into omega- 3 fatty acids, reducing the ratio of omega- 6 to -3 ratios from upwards of almost $49: 1$ in some tissues to less than $1: 1$ [116, 117]. Interestingly, islets isolated from fat-1 mice secrete more insulin at sub-stimulatory and stimulatory concentrations of glucose when compared to wild-type islets, indicating a potential role for islet LCPUFA composition in insulin secretion [117]. Moreover, fat- 1 islets produced less
AA-derived $\mathrm{PGE}_{2}$ compared to wild-type controls, suggesting a shift in prostaglandin production due to changes in LCPUFA composition [117]. When subject to diet-induced obesity, fat-1 mice are protected from glucose intolerance and overt diabetes [118-121]. Part of this protection is due to enhanced liver insulin sensitivity and improved $\beta$-cell morphology when compared to wild-type controls $[119,120]$. Moreover, the AA derived eicosanoids $\mathrm{PGE}_{2}$ and $\mathrm{LTB}_{4}$ were reduced in livers from fat- 1 mice, indicating a potential reduction in inflammation and shift in eicosanoid production [119]. To ascertain whether fat-1 mice would be protected from age-related blood glucose impairment, fat-1 mice were placed on nonobesogenic diet for 2 and 8 months. Interestingly, fat-1 mice were protected from developing glucose intolerance due in part to endogenous blood glucose production, indicating a potential benefit of enhanced omega-3 fatty acids in preventing agerelated metabolic disease [122]. Lastly, when fat-1 is strictly expressed in adipocytes, only male mice are protected from glucose intolerance (presumably due to enhanced insulin secretion) suggesting both sex-and tissue-specific effects of omega- 3 fatty acids [123].

In addition to diet-induced glucose intolerance mouse models, fat- 1 mice are protected from $\beta$-cell destruction in mouse models of type- 1 diabetes. When fat-1 mice are treated with streptozotocin (STZ) to induce type-1 diabetes, they do not become glucose intolerant and $\beta$-cell structure and function is preserved $[120,124]$. Furthermore, there was a reduction in islet cell apoptosis and markers of inflammation, including reduced production of the AA-specific eicosanoids $\mathrm{PGE}_{2}$ and 12-HETE [120, 124]. Interestingly, enhanced production of the EPA-specific eicosanoid 18-HEPE, which has anti-inflammatory properties, was also upregulated in $f a t-1$ mice treated with STZ, suggesting a shift in eicosanoid production based on substrate availability [124]. When isolated islets were subject to cytokine-induced destruction, fat -1 islets were protected from cell death indicating a role for LCPUFAs in apoptosis [117].

There is very little evidence regarding the influence of specific EPA-derived eicosanoids and insulin secretion or sensitivity. However, in addition to GPR119 serving as a receptor for phosphatidylcholine and ethanolamide compounds, it can also be activated by 5-hydroxy-eicosapentaenoic acid (5-HEPE), an EPA-derived eicosanoid formed by 5LOX [125]. In a mouse insulinoma cell line, it was shown that 5-HEPE bound specifically to GPR119 
and enhanced insulin secretion, suggesting GPR119 can be activated by a diverse set of ligands including eicosanoids [125]. Additionally, further metabolism of eicosanoids derived from EPA and docosahexaenoic acid (DHA) into compounds termed resolvins and protectins, respectively, may confer benefits to glucose homeostasis [126]. A hyperphagic mouse model fed a diet high in omega-3 fatty acids had enhanced production of resolvins and protectins, which ultimately led to increased insulin sensitivity [127]. Another study demonstrated that exogenous treatment with resolvin D1 improved insulin sensitivity and reduced fasting hyperglycemia in a hyperphagic mouse model further supporting the beneficial role for omega-3 eicosanoid metabolism in protection from glucose intolerance [128].

\section{Conclusions and future perspectives}

During the past several decades in the U.S., high dietary fat consumption was considered detrimental to health, even with poor or uncertain scientific justification, leading to a drastic and questionable shift in dietary recommendations for fat intake [129]. Ultimately, this shift did not reduce caloric intake or the prevalence of metabolic diseases, such as obesity and diabetes $[130,131]$. It is now becoming evident that a shift in the types of fats consumed may be far more important than an overall reduction in fat intake. This is particularly true with the bioactive LCPUFAs, with their potential role in contributing to or ameliorating chronic conditions such as obesity and diabetes $[4,5$, 129, 132].

Traditionally, omega- 6 fatty acids are considered more detrimental to health and promote disease primarily due to their pro-inflammatory properties. However, omega-6 LCPUFAs are absolutely required for the development, maturation, and function of the immune system [133]. Moreover, many human studies assessing the impact of omega-6 LCPUFA intake and cardiovascular risk fail to demonstrate any significant changes in AA content in cells or changes in pro-inflammatory markers [134-136]. Similar findings demonstrate that omega-3 supplementation does not appear to change morbidity or mortality or inflammatory markers associated with type- 2 diabetes [137]. Therefore, the essentiality of omega- 6 fatty acids and limited evidence linking omega- 6 LCPUFAs to inflammation in human studies hinder the direct link between omega-6 LCPUFAs and disease. But, the divergence in the ratio of omega- 6 to omega-3 fatty acids may inherently be the root of the problem as opposed to any quantity of omega- 6 LCPUFAs.

Perhaps more important than the species of LCPUFAs is the bioactive compounds they create. Pharmaceutical interventions to limit eicosanoid production, such as COX-2 inhibitors, are efficacious in potentiating insulin secretion and may provide additional benefits in insulin sensitivity in human patients [63, 138-140]. However, cardiovascular risk factors are a cause for concern regarding this treatment, as COX-2 inhibitors in type 2 diabetic patients may lead to adverse cardiac events, particularly in a population with increased basal risk [141, 142]. Moreover, antagonizing eicosanoid receptors as a therapeutic intervention is growing in interest and may be more efficacious in diabetic treatment $[14,21,143]$.

In an age where disease therapy is closely linked to pharmaceutical treatment, a dietary intervention promoting a LCPUFA profile similar to our ancestors may also prove beneficial in the prevention and treatment of both type 1 and 2 diabetes. The previously mentioned transgenic mouse models demonstrate the importance of the omega- 6 to omega- 3 ratios in directly and indirectly altering insulin sensitivity and secretion. Future dietary interventions designed to transform our eicosanoid profiles may prove to be a potential therapy for the long-term treatment of diabetes.

\section{References}

[1] Guariguata L, Whiting DR, Hambleton I, Beagley J, Linnenkamp U, Shaw JE. Global estimates of diabetes prevalence for 2013 and projections for 2035. Diabetes research and clinical practice. 2014;103(2):137-49. PubMed PMID: 24630390.

[2] Herman WH. The economic costs of diabetes: Is it time for a new treatment paradigm? Diabetes care. 2013;36(4):7756. PubMed PMID: 23520368. Pubmed Central PMCID: 3609514.

[3] Wild S, Roglic G, Green A, Sicree R, King H. Global prevalence of diabetes: Estimates for the year 2000 and projections for 2030. Diabetes care. 2004;27(5):1047-53. PubMed PMID: 15111519.

[4] Simopoulos AP. The importance of the ratio of omega6/omega-3 essential fatty acids. Biomed Pharmacother. 2002;56(8):365-79. PubMed PMID: 12442909.

[5] Simopoulos AP. Evolutionary aspects of diet, the omega-6/omega-3 ratio and genetic variation: Nutritional implications for chronic diseases. Biomed Pharmacother. 2006;60(9):502-7. PubMed PMID: 17045449.

[6] Ginsberg BH, Brown TJ, Simon I, Spector AA. Effect of the membrane lipid environment on the properties of insulin receptors. Diabetes. 1981;30(9):773-80. PubMed PMID: 6266903. 
[7] Luo P, Wang MH. Eicosanoids, beta-cell function, and diabetes. Prostaglandins Other Lipid Mediat. 2011;95(14):1-10. PubMed PMID: 21757024. Pubmed Central PMCID: PMC3144311.

[8] Riserus U, Willett WC, Hu FB. Dietary fats and prevention of type 2 diabetes. Prog Lipid Res. 2009;48(1):44-51. PubMed PMID: 19032965. Pubmed Central PMCID: PMC2654180.

[9] McGarry JD. Banting lecture 2001: Dysregulation of fatty acid metabolism in the etiology of type 2 diabetes. Diabetes. 2002;51(1):7-18. PubMed PMID: 11756317.

[10] McGarry JD, Dobbins RL. Fatty acids, lipotoxicity and insulin secretion. Diabetologia. 1999;42(2):128-38. PubMed PMID: 10064091.

[11] Dresner A, Laurent D, Marcucci M, Griffin ME, Dufour S, Cline GW, et al. Effects of free fatty acids on glucose transport and IRS-1-associated phosphatidylinositol 3-kinase activity. J Clin Invest. 1999;103(2):253-9. PubMed PMID: 9916137. Pubmed Central PMCID: PMC407880.

[12] Griffin ME, Marcucci MJ, Cline GW, Bell K, Barucci N, Lee D, et al. Free fatty acid-induced insulin resistance is associated with activation of protein kinase $\mathrm{C}$ theta and alterations in the insulin signaling cascade. Diabetes. 1999;48(6):1270-4. PubMed PMID: 10342815.

[13] Yeagle PL, Albert AD. G-protein coupled receptor structure. Biochim Biophys Acta. 2007;1768(4):808-24. PubMed PMID: 17097603.

[14] Kimple ME, Neuman JC, Linnemann AK, Casey PJ. Inhibitory $\mathrm{G}$ proteins and their receptors: Emerging therapeutic targets for obesity and diabetes. Exp Mol Med. 2014;46:e102. PubMed PMID: 24946790. Pubmed Central PMCID: PMC4081554.

[15] Wang Z, Thurmond DC. Mechanisms of biphasic insulingranule exocytosis - roles of the cytoskeleton, small GTPases and SNARE proteins. J Cell Sci. 2009;122(Pt 7): 893-903. PubMed PMID: 19295123. Pubmed Central PMCID: PMC2720925.

[16] Edvell A, Lindstrom P. Initiation of increased pancreatic islet growth in young normoglycemic mice (Umea +/?). Endocrinology. 1999;140(2):778-83. PubMed PMID: 9927305.

[17] Mojsov S, Weir GC, Habener JF. Insulinotropin: Glucagonlike peptide I (7-37) co-encoded in the glucagon gene is a potent stimulator of insulin release in the perfused rat pancreas. J Clin Invest. 1987;79(2):616-9. PubMed PMID: 3543057. Pubmed Central PMCID: PMC424143.

[18] Perfetti R, Zhou J, Doyle ME, Egan JM. Glucagon-like peptide-1 induces cell proliferation and pancreaticduodenum homeobox-1 expression and increases endocrine cell mass in the pancreas of old, glucose-intolerant rats. Endocrinology. 2000;141(12):4600-5. PubMed PMID: 11108273.

[19] Thorens B. Expression cloning of the pancreatic beta cell receptor for the gluco-incretin hormone glucagon-like peptide 1. Proc Natl Acad Sci U S A. 1992;89(18):86415. PubMed PMID: 1326760. Pubmed Central PMCID: PMC49976.

[20] Sassmann A, Gier B, Grone HJ, Drews G, Offermanns S, Wettschureck N. The Gq/G11-mediated signaling pathway is critical for autocrine potentiation of insulin secretion in mice. J Clin Invest. 2010;120(6):2184-93. PubMed PMID: 20440069. Pubmed Central PMCID: PMC2877950.
[21] Kimple ME, Keller MP, Rabaglia MR, Pasker RL, Neuman JC, Truchan NA, et al. Prostaglandin E2 receptor, $\mathrm{EP} 3$, is induced in diabetic islets and negatively regulates glucose- and hormone-stimulated insulin secretion. Diabetes. 2013;62(6):1904-12. PubMed PMID: 23349487. Pubmed Central PMCID: PMC3661627.

[22] Kimple ME, Nixon AB, Kelly P, Bailey CL, Young KH, Fields TA, et al. A role for $G(z)$ in pancreatic islet beta-cell biology. The Journal of biological chemistry. 2005;280(36):31708-13. PubMed PMID: 16157560.

[23] Robertson RP, Tsai P, Little SA, Zhang HJ, Walseth TF. Receptor-mediated adenylate cyclase-coupled mechanism for PGE2 inhibition of insulin secretion in HIT cells. Diabetes. 1987;36(9):1047-53. PubMed PMID: 2886385.

[24] Sabbatini ME, Bi Y, Ji B, Ernst SA, Williams JA. CCK activates RhoA and Rac1 differentially through Galpha13 and Galphaq in mouse pancreatic acini. Am J Physiol Cell Physiol. 2010;298(3):C592-601. PubMed PMID: 19940064. Pubmed Central PMCID: PMC2838570.

[25] Ulven T. Short-chain free fatty acid receptors FFA2/GPR43 and FFA3/GPR41 as new potential therapeutic targets. Front Endocrinol (Lausanne). 2012;3:111. PubMed PMID: 23060857. Pubmed Central PMCID: PMC3462324.

[26] Overton HA, Babbs AJ, Doel SM, Fyfe MC, Gardner LS, Griffin G, et al. Deorphanization of a $\mathrm{G}$ protein-coupled receptor for oleoylethanolamide and its use in the discovery of small-molecule hypophagic agents. Cell Metab. 2006;3(3):167-75. PubMed PMID: 16517404.

[27] Soga T, Ohishi T, Matsui T, Saito T, Matsumoto M, Takasaki J, et al. Lysophosphatidylcholine enhances glucose-dependent insulin secretion via an orphan Gprotein-coupled receptor. Biochem Biophys Res Commun. 2005;326(4):744-51. PubMed PMID: 15607732.

[28] Chu ZL, Carroll C, Alfonso J, Gutierrez V, He H, Lucman A, et al. A role for intestinal endocrine cellexpressed g protein-coupled receptor 119 in glycemic control by enhancing glucagon-like Peptide- 1 and glucosedependent insulinotropic Peptide release. Endocrinology. 2008;149(5):2038-47. PubMed PMID: 18202141.

[29] Chu ZL, Jones RM, He H, Carroll C, Gutierrez V, Lucman A, et al. A role for beta-cell-expressed $G$ protein-coupled receptor 119 in glycemic control by enhancing glucose-dependent insulin release. Endocrinology. 2007;148(6):2601-9. PubMed PMID: 17289847.

[30] Hamm HE. The many faces of $G$ protein signaling. The Journal of biological chemistry. 1998;273(2):669-72. PubMed PMID: 9422713.

[31] Wettschureck N, Offermanns S. Mammalian G proteins and their cell type specific functions. Physiological reviews. 2005;85(4):1159-204. PubMed PMID: 16183910.

[32] Brown AJ, Jupe S, Briscoe CP. A family of fatty acid binding receptors. DNA Cell Biol. 2005;24(1):54-61. PubMed PMID: 15684720.

[33] Itoh Y, Kawamata Y, Harada M, Kobayashi M, Fujii R, Fukusumi S, et al. Free fatty acids regulate insulin secretion from pancreatic beta cells through GPR40. Nature. 2003;422(6928):173-6. PubMed PMID: 12629551.

[34] Kotarsky K, Nilsson NE, Flodgren E, Owman C, Olde B. A human cell surface receptor activated by free fatty acids and thiazolidinedione drugs. Biochem Biophys Res Commun. 2003;301(2):406-10. PubMed PMID: 12565875. 
[35] Kebede M, Alquier T, Latour MG, Semache M, Tremblay C, Poitout V. The fatty acid receptor GPR40 plays a role in insulin secretion in vivo after high-fat feeding. Diabetes. 2008;57(9):2432-7. PubMed PMID: 18559658. Pubmed Central PMCID: PMC2518494.

[36] Araki T, Hirayama M, Hiroi S, Kaku K. GPR40-induced insulin secretion by the novel agonist TAK-875: First clinical findings in patients with type 2 diabetes. Diabetes Obes Metab. 2012;14(3):271-8. PubMed PMID: 22051148.

[37] Briscoe CP, Peat AJ, McKeown SC, Corbett DF, Goetz AS, Littleton TR, et al. Pharmacological regulation of insulin secretion in MIN6 cells through the fatty acid receptor GPR40: Identification of agonist and antagonist small molecules. Br J Pharmacol. 2006;148(5):619-28. PubMed PMID: 16702987. Pubmed Central PMCID: PMC1751878.

[38] Sun P, Wang T, Zhou Y, Liu H, Jiang H, Zhu W, et al. DC260126: A small-molecule antagonist of GPR40 that protects against pancreatic beta-Cells dysfunction in db/db mice. PLoS One. 2013;8(6):e66744. PubMed PMID: 23776696. Pubmed Central PMCID: PMC3679087.

[39] Zhang X, Yan G, Li Y, Zhu W, Wang H. DC260126, a small-molecule antagonist of GPR40, improves insulin tolerance but not glucose tolerance in obese Zucker rats. Biomed Pharmacother. 2010;64(9):647-51. PubMed PMID: 20888730.

[40] Ichimura A, Hirasawa A, Poulain-Godefroy O, Bonnefond A, Hara T, Yengo L, et al. Dysfunction of lipid sensor GPR120 leads to obesity in both mouse and human. Nature. 2012;483(7389):350-4. PubMed PMID: 22343897.

[41] Oh DY, Talukdar S, Bae EJ, Imamura T, Morinaga H, Fan W, et al. GPR120 is an omega-3 fatty acid receptor mediating potent anti-inflammatory and insulin-sensitizing effects. Cell. 2010;142(5):687-98. PubMed PMID: 20813258. Pubmed Central PMCID: PMC2956412.

[42] Talukdar S, Olefsky JM, Osborn O. Targeting GPR120 and other fatty acid-sensing GPCRs ameliorates insulin resistance and inflammatory diseases. Trends Pharmacol Sci. 2011;32(9):543-50. PubMed PMID: 21663979. Pubmed Central PMCID: PMC3419590.

[43] Hirasawa A, Tsumaya K, Awaji T, Katsuma S, Adachi T, Yamada $\mathrm{M}$, et al. Free fatty acids regulate gut incretin glucagon-like peptide-1 secretion through GPR120. Nat Med. 2005;11(1):90-4. PubMed PMID: 15619630.

[44] Iwasaki K, Harada N, Sasaki K, Yamane S, Iida K, Suzuki $\mathrm{K}$, et al. Free fatty acid receptor GPR 120 is highly expressed in enteroendocrine $\mathrm{K}$ cells of the upper small intestine and has a critical role in GIP secretion after fat ingestion. Endocrinology. 2015;156(3):837-46. PubMed PMID: 25535828.

[45] Tanaka T, Katsuma S, Adachi T, Koshimizu TA, Hirasawa A, Tsujimoto G. Free fatty acids induce cholecystokinin secretion through GPR120. Naunyn Schmiedebergs Arch Pharmacol. 2008;377(4-6):523-7. PubMed PMID: 17972064.

[46] Larsson SC, Kumlin M, Ingelman-Sundberg M, Wolk A. Dietary long-chain n-3 fatty acids for the prevention of cancer: A review of potential mechanisms. Am J Clin Nutr. 2004;79(6):935-45. PubMed PMID: 15159222.

[47] Rose DP, Connolly JM. Omega-3 fatty acids as cancer chemopreventive agents. Pharmacol Ther. 1999;83(3):21744. PubMed PMID: 10576293.
[48] Persaud SJ, Muller D, Belin VD, Kitsou-Mylona I, Asare-Anane H, Papadimitriou A, et al. The role of arachidonic acid and its metabolites in insulin secretion from human islets of langerhans. Diabetes. 2007;56(1):197-203. PubMed PMID: 17192482.

[49] Dennis EA, Norris PC. Eicosanoid storm in infection and inflammation. Nat Rev Immunol. 2015;15(8):51123. PubMed PMID: 26139350. Pubmed Central PMCID: PMC4606863.

[50] Lin LL, Wartmann M, Lin AY, Knopf JL, Seth A, Davis RJ. cPLA2 is phosphorylated and activated by MAP kinase. Cell. 1993;72(2):269-78. PubMed PMID: 8381049.

[51] Nemenoff RA, Winitz S, Qian NX, Van Putten V, Johnson GL, Heasley LE. Phosphorylation and activation of a high molecular weight form of phospholipase A2 by p42 microtubule-associated protein 2 kinase and protein kinase C. The Journal of Biological Chemistry. 1993;268(3):19604. PubMed PMID: 8380583.

[52] Folco G, Murphy RC. Eicosanoid transcellular biosynthesis: From cell-cell interactions to in vivo tissue responses. Pharmacol Rev. 2006;58(3):375-88. PubMed PMID: 16968946.

[53] Vane JR, Bakhle YS, Botting RM. Cyclooxygenases 1 and 2. Annu Rev Pharmacol Toxicol. 1998;38:97-120. PubMed PMID: 9597150.

[54] Robertson RP. Dominance of cyclooxygenase- 2 in the regulation of pancreatic islet prostaglandin synthesis. Diabetes. 1998;47(9):1379-83. PubMed PMID: 9726224.

[55] Sorli CH, Zhang HJ, Armstrong MB, Rajotte RV, Maclouf J, Robertson RP. Basal expression of cyclooxygenase-2 and nuclear factor-interleukin 6 are dominant and coordinately regulated by interleukin 1 in the pancreatic islet. Proc Natl Acad Sci U S A. 1998;95(4):1788-93. PubMed PMID: 9465095. Pubmed Central PMCID: PMC19191.

[56] Breyer RM, Bagdassarian CK, Myers SA, Breyer MD. Prostanoid receptors: Subtypes and signaling. Annu Rev Pharmacol Toxicol. 2001;41:661-90. PubMed PMID: 11264472 .

[57] Johnson DG, Fujimoto WY, Williams RH. Enhanced release of insulin by prostaglandins in isolated pancreatic islets. Diabetes. 1973;22(9):658-63. PubMed PMID: 4353850.

[58] Metz S, VanRollins M, Strife R, Fujimoto W, Robertson RP. Lipoxygenase pathway in islet endocrine cells. Oxidative metabolism of arachidonic acid promotes insulin release. J Clin Invest. 1983;71(5):1191-205. PubMed PMID: 6406544. Pubmed Central PMCID: PMC436979.

[59] Oshima H, Taketo MM, Oshima M. Destruction of pancreatic beta-cells by transgenic induction of prostaglandin E2 in the islets. The Journal of Biological Chemistry. 2006;281(39):29330-6. PubMed PMID: 16873378.

[60] Robertson RP. Arachidonic acid metabolite regulation of insulin secretion. Diabetes Metab Rev. 1986;2(3-4):261-96. PubMed PMID: 3091336.

[61] Burr IM, Sharp R. Effects of prostaglandin E1 and of epinephrine on the dynamics of insulin release in vitro. Endocrinology. 1974;94(3):835-9. PubMed PMID: 4591826.

[62] Robertson RP, Gavareski DJ, Porte D Jr, Bierman EL. Inhibition of in vivo insulin secretion by prostaglandin E1. J Clin Invest. 1974;54(2):310-5. PubMed PMID: 4847247. Pubmed Central PMCID: PMC301558. 
[63] Tran PO, Gleason CE, Robertson RP. Inhibition of interleukin-1beta-induced COX-2 and EP3 gene expression by sodium salicylate enhances pancreatic islet beta-cell function. Diabetes. 2002;51(6):1772-8. PubMed PMID: 12031964.

[64] Henkel J, Neuschafer-Rube F, Pathe-Neuschafer-Rube A, Puschel GP. Aggravation by prostaglandin E2 of interleukin-6-dependent insulin resistance in hepatocytes. Hepatology. 2009;50(3):781-90. PubMed PMID: 19575453.

[65] Henkel J, Gartner D, Dorn C, Hellerbrand C, Schanze N, Elz SR, et al. Oncostatin M produced in Kupffer cells in response to PGE2: Possible contributor to hepatic insulin resistance and steatosis. Lab Invest. 2011;91(7):1107-17. PubMed PMID: 21519329.

[66] Hsieh PS, Jin JS, Chiang CF, Chan PC, Chen CH, Shih KC. COX-2-mediated inflammation in fat is crucial for obesity-linked insulin resistance and fatty liver. Obesity (Silver Spring). 2009;17(6):1150-7. PubMed PMID: 19247274.

[67] Hsieh PS, Tsai HC, Kuo CH, Chan JY, Shyu JF, Cheng WT, et al. Selective COX2 inhibition improves whole body and muscular insulin resistance in fructose-fed rats. Eur J Clin Invest. 2008;38(11):812-9. PubMed PMID: 19021698.

[68] Tian YF, Hsia TL, Hsieh CH, Huang DW, Chen CH, Hsieh PS. The importance of cyclooxygenase 2-mediated oxidative stress in obesity-induced muscular insulin resistance in high-fat-fed rats. Life Sci. 2011;89(3-4):107-14. PubMed PMID: 21640730.

[69] Coll T, Palomer X, Blanco-Vaca F, Escola-Gil JC, Sanchez RM, Laguna JC, et al. Cyclooxygenase 2 inhibition exacerbates palmitate-induced inflammation and insulin resistance in skeletal muscle cells. Endocrinology. 2010;151(2):537-48. PubMed PMID: 20022932.

[70] Frances DE, Motino O, Agra N, Gonzalez-Rodriguez A, Fernandez-Alvarez A, Cucarella C, et al. Hepatic cyclooxygenase- 2 expression protects against diet-induced steatosis, obesity, and insulin resistance. Diabetes. 2015;64(5):1522-31. PubMed PMID: 25422106.

[71] Turk J, Hughes JH, Easom RA, Wolf BA, Scharp DW, Lacy PE, et al. Arachidonic acid metabolism and insulin secretion by isolated human pancreatic islets. Diabetes. 1988;37(7):992-6. PubMed PMID: 3133262.

[72] Horie H, Narumiya S, Matsuyama T, Nonaka K, Tarui S. Presence of prostaglandin D2, E2 and F2 alpha in rat pancreatic islets. Prostaglandins Leukot Med. 1984;16(1):39-44. PubMed PMID: 6393143.

[73] Akpan JO, Hurley MC, Pek S, Lands WE. The effects of prostaglandins on secretion of glucagon and insulin by the perfused rat pancreas. Can J Biochem. 1979;57(6):540-7. PubMed PMID: 383232.

[74] Fujitani Y, Aritake K, Kanaoka Y, Goto T, Takahashi $\mathrm{N}$, Fujimori K, et al. Pronounced adipogenesis and increased insulin sensitivity caused by overproduction of prostaglandin D2 in vivo. FEBS J. 2010;277(6):1410-9. PubMed PMID: 20136655.

[75] Ragolia L, Palaia T, Hall CE, Maesaka JK, Eguchi $\mathrm{N}$, Urade Y. Accelerated glucose intolerance, nephropathy, and atherosclerosis in prostaglandin D2 synthase knock-out mice. The Journal of Biological Chemistry. 2005;280(33):29946-55. PubMed PMID: 15970590.
[76] Pek S, Tai TY, Elster A. Stimulatory effects of prostaglandins E-1, E-2, and F-2-alpha on glucagon and insulin release in vitro. Diabetes. 1978;27(8):801-9. PubMed PMID: 680407.

[77] Gopaul NK, Anggard EE, Mallet AI, Betteridge DJ, Wolff SP, Nourooz-Zadeh J. Plasma 8-epi-PGF2 alpha levels are elevated in individuals with non-insulin dependent diabetes mellitus. FEBS Lett. 1995;368(2):225-9. PubMed PMID: 7628610 .

[78] Klein T, Reutter F, Schweer H, Seyberth HW, Nusing RM. Generation of the isoprostane 8-epi-prostaglandin F2alpha in vitro and in vivo via the cyclooxygenases. J Pharmacol Exp Ther. 1997;282(3):1658-65. PubMed PMID: 9316884.

[79] Dembinska-Kiec A, Kostka-Trabka E, Grodzinska L, Zmuda A, Bieron K, Kedzior A, et al. Prostacyclin and blood glucose levels in humans and rabbits. Prostaglandins. 1981;21(1):113-21. PubMed PMID: 7010454.

[80] Patrono C, Pugliese F, Ciabattoni G, Di Blasi S, Pierucci A, Cinotti GA, et al. Prostacyclin does not affect insulin secretion in humans. Prostaglandins. 1981;21(3):379-85. PubMed PMID: 7015416.

[81] Heaney TP, Larkins RG. The effect of prostacyclin and 6-keto-prostaglandin F1 alpha on insulin secretion and cyclic adenosine $3^{\prime}, 5^{\prime}$-monophosphate content in isolated rat islets. Diabetes. 1981;30(10):824-8. PubMed PMID: 6168507.

[82] Sieradzki J, Wolan H, Szczeklik A. Effects of prostacyclin and its stable analog, iloprost, upon insulin secretion in isolated pancreatic islets. Prostaglandins. 1984;28(3):28996. PubMed PMID: 6083582.

[83] Gurgul-Convey E, Hanzelka K, Lenzen S. Mechanism of prostacyclin-induced potentiation of glucose-induced insulin secretion. Endocrinology. 2012;153(6):2612-22. PubMed PMID: 22495672.

[84] Angiolillo DJ, Fernandez-Ortiz A, Bernardo E, Ramirez C, Sabate M, Jimenez-Quevedo P, et al. Platelet function profiles in patients with type 2 diabetes and coronary artery disease on combined aspirin and clopidogrel treatment. Diabetes. 2005;54(8):2430-5. PubMed PMID: 16046311.

[85] Davi G, Catalano I, Averna M, Notarbartolo A, Strano A, Ciabattoni G, et al. Thromboxane biosynthesis and platelet function in type II diabetes mellitus. N Engl J Med. 1990;322(25):1769-74. PubMed PMID: 2345567.

[86] Ziboh VA, Maruta H, Lord J, Cagle WD, Lucky W. Increased biosynthesis of thromboxane A2 by diabetic platelets. Eur J Clin Invest. 1979;9(3):223-8. PubMed PMID: 113223.

[87] Brash AR. Lipoxygenases: Occurrence, functions, catalysis, and acquisition of substrate. The Journal of biological chemistry. 1999;274(34):23679-82. PubMed PMID: 10446122.

[88] Metz SA. Glucose increases the synthesis of lipoxygenasemediated metabolites of arachidonic acid in intact rat islets. Proc Natl Acad Sci U S A. 1985;82(1):198202. PubMed PMID: 3918302. Pubmed Central PMCID: PMC396999.

[89] Turk J, Colca JR, Kotagal N, McDaniel ML. Arachidonic acid metabolism in isolated pancreatic islets. I. Identification and quantitation of lipoxygenase and cyclooxygenase products. Biochim Biophys Acta. 1984;794(1):110-24. PubMed PMID: 6329307. 
[90] Turk J, Colca JR, Kotagal N, McDaniel ML. Arachidonic acid metabolism in isolated pancreatic islets. II. The effects of glucose and of inhibitors of arachidonate metabolism on insulin secretion and metabolite synthesis. Biochim Biophys Acta. 1984;794(1):125-36. PubMed PMID: 6428455.

[91] Turk J, Colca JR, McDaniel ML. Arachidonic acid metabolism in isolated pancreatic islets. III. Effects of exogenous lipoxygenase products and inhibitors on insulin secretion. Biochim Biophys Acta. 1985;834(1):23-36. PubMed PMID: 3919770.

[92] Metz SA, Murphy RC, Fujimoto W. Effects on glucose-induced insulin secretion of lipoxygenase-derived metabolites of arachidonic acid. Diabetes. 1984;33(2):11924. PubMed PMID: 6319213.

[93] Mehrabian M, Schulthess FT, Nebohacova M, Castellani LW, Zhou Z, Hartiala J, et al. Identification of ALOX5 as a gene regulating adiposity and pancreatic function. Diabetologia. 2008;51(6):978-88. PubMed PMID: 18421434. Pubmed Central PMCID: PMC2835627.

[94] Ma K, Nunemaker CS, Wu R, Chakrabarti SK, TaylorFishwick DA, Nadler JL. 12-Lipoxygenase Products Reduce Insulin Secretion and beta-Cell Viability in Human Islets. J Clin Endocrinol Metab. 2010;95(2):88793. PubMed PMID: 20089617. Pubmed Central PMCID: PMC2840856.

[95] Bleich D, Chen S, Zipser B, Sun D, Funk CD, Nadler JL. Resistance to type 1 diabetes induction in 12-lipoxygenase knockout mice. J Clin Invest. 1999;103(10):1431-6. PubMed PMID: 10330425. Pubmed Central PMCID: PMC408453.

[96] Chen M, Yang ZD, Smith KM, Carter JD, Nadler JL. Activation of 12-lipoxygenase in proinflammatory cytokine-mediated beta cell toxicity. Diabetologia. 2005;48(3):486-95. PubMed PMID: 15729574.

[97] Chakrabarti SK, Cole BK, Wen Y, Keller SR, Nadler JL. 12/15-lipoxygenase products induce inflammation and impair insulin signaling in 3T3-L1 adipocytes. Obesity (Silver Spring). 2009;17(9):1657-63. PubMed PMID: 19521344. Pubmed Central PMCID: PMC2887741.

[98] Nunemaker CS, Chen M, Pei H, Kimble SD, Keller SR, Carter JD, et al. 12-Lipoxygenase-knockout mice are resistant to inflammatory effects of obesity induced by Western diet. Am J Physiol Endocrinol Metab. 2008;295(5):E106575. PubMed PMID: 18780776. Pubmed Central PMCID: PMC2584815.

[99] Ahren B, Magrum LJ, Havel PJ, Greene SF, Phinney SD, Johnson PR, et al. Augmented insulinotropic action of arachidonic acid through the lipoxygenase pathway in the obese Zucker rat. Obes Res. 2000;8(6):475-80. PubMed PMID: 11011915.

[100] Chakrabarti SK, Wen Y, Dobrian AD, Cole BK, Ma Q, Pei $\mathrm{H}$, et al. Evidence for activation of inflammatory lipoxygenase pathways in visceral adipose tissue of obese Zucker rats. Am J Physiol Endocrinol Metab. 2011;300(1):E17587. PubMed PMID: 20978234. Pubmed Central PMCID: PMC3023204.

[101] McDuffie M, Maybee NA, Keller SR, Stevens BK, Garmey JC, Morris MA, et al. Nonobese diabetic (NOD) mice congenic for a targeted deletion of 12/15lipoxygenase are protected from autoimmune diabetes.
Diabetes. 2008;57(1):199-208. PubMed PMID: 17940120. Pubmed Central PMCID: PMC2993320.

[102] Spector AA. Arachidonic acid cytochrome P450 epoxygenase pathway. J Lipid Res. 2009;50(Suppl):S52-6. PubMed PMID: 18952572. Pubmed Central PMCID: PMC2674692.

[103] Falck JR, Manna S, Moltz J, Chacos N, Capdevila J. Epoxyeicosatrienoic acids stimulate glucagon and insulin release from isolated rat pancreatic islets. Biochem Biophys Res Commun. 1983;114(2):743-9. PubMed PMID: 6411091.

[104] Zeldin DC, Foley J, Boyle JE, Moomaw CR, Tomer KB, Parker $\mathrm{C}$, et al. Predominant expression of an arachidonate epoxygenase in islets of Langerhans cells in human and rat pancreas. Endocrinology. 1997;138(3):1338-46. PubMed PMID: 9048644

[105] Luo P, Chang HH, Zhou Y, Zhang S, Hwang SH, Morisseau $\mathrm{C}$, et al. Inhibition or deletion of soluble epoxide hydrolase prevents hyperglycemia, promotes insulin secretion, and reduces islet apoptosis. J Pharmacol Exp Ther. 2010;334(2):430-8. PubMed PMID: 20439437. Pubmed Central PMCID: PMC2913776.

[106] Luria A, Bettaieb A, Xi Y, Shieh GJ, Liu HC, Inoue H, et al. Soluble epoxide hydrolase deficiency alters pancreatic islet size and improves glucose homeostasis in a model of insulin resistance. Proc Natl Acad Sci U S A. 2011;108(22):903843. PubMed PMID: 21571638. Pubmed Central PMCID: PMC3107315.

[107] Ramirez CE, Shuey MM, Milne GL, Gilbert K, Hui N, Yu C, et al. Arg287Gln variant of EPHX2 and epoxyeicosatrienoic acids are associated with insulin sensitivity in humans. Prostaglandins Other Lipid Mediat. 2014;113115:38-44. PubMed PMID: 25173047. Pubmed Central PMCID: PMC4253976.

[108] Grimm H, Mayer K, Mayser P, Eigenbrodt E. Regulatory potential of n-3 fatty acids in immunological and inflammatory processes. Br J Nutr. 2002;87(Suppl 1):S59-67. PubMed PMID: 11895155.

[109] Figueras M, Olivan M, Busquets S, Lopez-Soriano FJ, Argiles JM. Effects of eicosapentaenoic acid (EPA) treatment on insulin sensitivity in an animal model of diabetes: Improvement of the inflammatory status. Obesity (Silver Spring). 2011;19(2):362-9. PubMed PMID: 20885391.

[110] Lalia AZ, Johnson ML, Jensen MD, Hames KC, Port JD, Lanza IR. Effects of dietary n-3 fatty acids on hepatic and peripheral insulin sensitivity in insulin-resistant humans. Diabetes care. 2015;38(7):1228-37. PubMed PMID: 25852206. Pubmed Central PMCID: PMC4477338.

[111] Popp-Snijders C, Schouten JA, Heine RJ, van der Meer J, van der Veen EA. Dietary supplementation of omega-3 polyunsaturated fatty acids improves insulin sensitivity in non-insulin-dependent diabetes. Diabetes Res. 1987;4(3):141-7. PubMed PMID: 3038454.

[112] Storlien LH, Jenkins AB, Chisholm DJ, Pascoe WS, Khouri $\mathrm{S}$, Kraegen EW. Influence of dietary fat composition on development of insulin resistance in rats. Relationship to muscle triglyceride and omega-3 fatty acids in muscle phospholipid. Diabetes. 1991;40(2):280-9. PubMed PMID: 1991575.

[113] Storlien LH, Kraegen EW, Chisholm DJ, Ford GL, Bruce DG, Pascoe WS. Fish oil prevents insulin resistance induced 
by high-fat feeding in rats. Science. 1987;237(4817):885-8. PubMed PMID: 3303333.

[114] Xun P, He K. Fish consumption and incidence of diabetes: Meta-analysis of data from 438,000 individuals in 12 independent prospective cohorts with an average 11-year follow-up. Diabetes care. 2012;35(4):930-8. PubMed PMID: 22442398. Pubmed Central PMCID: PMC3308299.

[115] Buckley JD, Howe PR. Anti-obesity effects of longchain omega-3 polyunsaturated fatty acids. Obes Rev. 2009;10(6):648-59. PubMed PMID: 19460115.

[116] Kang JX, Wang J, Wu L, Kang ZB. Transgenic mice: Fat-1 mice convert n-6 to n-3 fatty acids. Nature. 2004; 427(6974):504. PubMed PMID: 14765186.

[117] Wei D, Li J, Shen M, Jia W, Chen N, Chen T, et al. Cellular production of n-3 PUFAs and reduction of n-6-to-n-3 ratios in the pancreatic beta-cells and islets enhance insulin secretion and confer protection against cytokine-induced cell death. Diabetes. 2010;59(2):471-8. PubMed PMID: 19933995. Pubmed Central PMCID: PMC2809969.

[118] Belchior T, Paschoal VA, Magdalon J, Chimin P, Farias TM, Chaves-Filho AB, et al. Omega-3 fatty acids protect from diet-induced obesity, glucose intolerance, and adipose tissue inflammation through PPARgamma-dependent and PPARgamma-independent actions. Mol Nutr Food Res. 2015;59(5):957-67. PubMed PMID: 25641959.

[119] Li J, Li FR, Wei D, Jia W, Kang JX, Stefanovic-Racic $\mathrm{M}$, et al. Endogenous omega-3 polyunsaturated fatty acid production confers resistance to obesity, dyslipidemia, and diabetes in mice. Mol Endocrinol. 2014;28(8):1316-28. PubMed PMID: 24978197.

[120] Wang J, Song MY, Bae UJ, Lim JM, Kwon KS, Park BH. n-3 Polyunsaturated fatty acids protect against pancreatic beta-cell damage due to ER stress and prevent diabetes development. Mol Nutr Food Res. 2015;59(9):1791-802. PubMed PMID: 26080997.

[121] White PJ, Arita M, Taguchi R, Kang JX, Marette A. Transgenic restoration of long-chain n-3 fatty acids in insulin target tissues improves resolution capacity and alleviates obesity-linked inflammation and insulin resistance in high-fat-fed mice. Diabetes. 2010;59(12):3066-73. PubMed PMID: 20841610. Pubmed Central PMCID: PMC2992767.

[122] Romanatto T, Fiamoncini J, Wang B, Curi R, Kang JX. Elevated tissue omega-3 fatty acid status prevents age-related glucose intolerance in fat-1 transgenic mice. Biochim Biophys Acta. 2014;1842(2):186-91. PubMed PMID: 24211484.

[123] Ji S, Hardy RW, Wood PA. Transgenic expression of n3 fatty acid desaturase (fat-1) in C57/BL6 mice: Effects on glucose homeostasis and body weight. J Cell Biochem. 2009;107(4):809-17. PubMed PMID: 19396841. Pubmed Central PMCID: PMC2763528.

[124] Bellenger J, Bellenger S, Bataille A, Massey KA, Nicolaou A, Rialland M, et al. High pancreatic n-3 fatty acids prevent STZ-induced diabetes in fat-1 mice: Inflammatory pathway inhibition. Diabetes. 2011;60(4):1090-9. PubMed PMID: 21330635. Pubmed Central PMCID: PMC3064083.

[125] Kogure R, Toyama K, Hiyamuta S, Kojima I, Takeda S. 5Hydroxy-eicosapentaenoic acid is an endogenous GPR119 agonist and enhances glucose-dependent insulin secretion.
Biochem Biophys Res Commun. 2011;416(1-2):58-63. PubMed PMID: 22079287.

[126] Spite M, Claria J, Serhan CN. Resolvins, specialized proresolving lipid mediators, and their potential roles in metabolic diseases. Cell Metab. 2014;19(1):21-36. PubMed PMID: 24239568. Pubmed Central PMCID: PMC3947989.

[127] Gonzalez-Periz A, Horrillo R, Ferre N, Gronert K, Dong $\mathrm{B}$, Moran-Salvador E, et al. Obesity-induced insulin resistance and hepatic steatosis are alleviated by omega-3 fatty acids: A role for resolvins and protectins. FASEB J. 2009;23(6):1946-57. PubMed PMID: 19211925. Pubmed Central PMCID: PMC2698663.

[128] Hellmann J, Tang Y, Kosuri M, Bhatnagar A, Spite M. Resolvin D1 decreases adipose tissue macrophage accumulation and improves insulin sensitivity in obese-diabetic mice. FASEB J. 2011;25(7):2399-407. PubMed PMID: 21478260. Pubmed Central PMCID: PMC3114534.

[129] Hu FB, Manson JE, Willett WC. Types of dietary fat and risk of coronary heart disease: A critical review. J Am Coll Nutr. 2001;20(1):5-19. PubMed PMID: 11293467.

[130] Mokdad AH, Ford ES, Bowman BA, Nelson DE, Engelgau MM, Vinicor F, et al. Diabetes trends in the U.S.: 19901998. Diabetes care. 2000;23(9):1278-83. PubMed PMID: 10977060.

[131] Mokdad AH, Serdula MK, Dietz WH, Bowman BA, Marks JS, Koplan JP. The spread of the obesity epidemic in the United States, 1991-1998. JAMA. 1999;282(16):1519-22. PubMed PMID: 10546690.

[132] Simopoulos AP. The importance of the omega-6/omega-3 fatty acid ratio in cardiovascular disease and other chronic diseases. Exp Biol Med (Maywood). 2008;233(6):674-88. PubMed PMID: 18408140.

[133] Harbige LS. Fatty acids, the immune response, and autoimmunity: A question of n- 6 essentiality and the balance between n-6 and n-3. Lipids. 2003;38(4):323-41. PubMed PMID: 12848277.

[134] Farvid MS, Ding M, Pan A, Sun Q, Chiuve SE, Steffen LM, et al. Dietary linoleic acid and risk of coronary heart disease: A systematic review and meta-analysis of prospective cohort studies. Circulation. 2014;130(18):1568-78. PubMed PMID: 25161045. Pubmed Central PMCID: PMC4334131.

[135] Johnson GH, Fritsche K. Effect of dietary linoleic acid on markers of inflammation in healthy persons: A systematic review of randomized controlled trials. J Acad Nutr Diet. 2012;112(7):1029-41, 41 e1-15. PubMed PMID: 22889633.

[136] Rett BS, Whelan J. Increasing dietary linoleic acid does not increase tissue arachidonic acid content in adults consuming Western-type diets: A systematic review. Nutr Metab (Lond). 2011;8:36. PubMed PMID: 21663641. Pubmed Central PMCID: PMC3132704.

[137] Jeppesen C, Schiller K, Schulze MB. Omega-3 and omega- 6 fatty acids and type 2 diabetes. Curr Diab Rep. 2013;13(2):279-88. PubMed PMID: 23325534.

[138] Fernandez-Real JM, Lopez-Bermejo A, Ropero AB, Piquer S, Nadal A, Bassols J, et al. Salicylates increase insulin secretion in healthy obese subjects. J Clin Endocrinol Metab. 2008;93(7):2523-30. PubMed PMID: 18460568.

[139] Goldfine AB, Conlin PR, Halperin F, Koska J, Permana P, Schwenke D, et al. A randomised trial of salsalate for insulin 
resistance and cardiovascular risk factors in persons with abnormal glucose tolerance. Diabetologia. 2013;56(4):71423. PubMed PMID: 23370525.

[140] Robertson RP, Chen M. A role for prostaglandin E in defective insulin secretion and carbohydrate intolerance in diabetes mellitus. JClin Invest. 1977;60(3):747-53. PubMed PMID: 330566. Pubmed Central PMCID: PMC372420.

[141] Becker RC. COX-2 inhibitors. Tex Heart Inst J. 2005;32(3):380-3. PubMed PMID: 16392224. Pubmed Central PMCID: PMC1336714.
[142] Smith CJ, McKay GA, Fisher M. Diabetes, colorectal cancer and cyclooxygenase 2 inhibition. Int $\mathrm{J}$ Clin Pract. 2008;62(5):810-5. PubMed PMID: 18373616.

[143] Neuman JC, Kimple ME. The EP3 Receptor: Exploring a New Target for Type 2 Diabetes Therapeutics. J Endocrinol Diabetes Obes. 2013;1(1). PubMed PMID: 26322320. Pubmed Central PMCID: PMC4551503. 